NOTE

\title{
Viremia during infectious salmon anemia virus infection of Atlantic salmon is associated with replicating virus in leucocytes
}

\author{
Emeka Moneke, Basil O. Ikede, Frederick S. B. Kibenge* \\ Department of Pathology and Microbiology, Atlantic Veterinary College, University of Prince Edward Island, \\ 550 University Avenue, Charlottetown, Prince Edwards Island C1A 4P3, Canada
}

\begin{abstract}
In situ hybridization (ISH) was used to investigate the presence of viral mRNA in different fractions of blood cells of Atlantic salmon between 6 and $12 \mathrm{~d}$ following experimental infection with infectious salmon anemia virus (ISAV). Using a riboprobe targeting ISAV segment 7 mRNA, hybridization signals were observed only in leucocytes in buffy coat smears from samples collected from 8 to 12 d post-infection (dpi). None of the red blood cell smears from any sample showed ISH signal. These observations allow us to conclude that viremia in ISAV infection is associated with virus replication in leucocytes, and that erythrocytes are not target cells for virus replication.
\end{abstract}

KEY WORDS: ISAV · Cell-associated viremia $\cdot$ In situ hybridization · Atlantic salmon

\section{INTRODUCTION}

Infectious salmon anemia (ISA) is a highly fatal disease of marine-farmed Atlantic salmon Salmo salar L. caused by ISA virus (ISAV). The virus was recently classified in the virus family Orthomyxoviridae in the genus Isavirus (Anonymous 2001). Clinical ISA disease is characterized by exophthalmia, pale gills, ascites, decreased hematocrit value, congestion of gut, enlargement of liver and spleen, petechia hemorrhages in the visceral organs, severe anemia and variable mortality (Thorud \& Djupvik 1988, Evensen et al. 1991). To date there have been conflicting reports on the blood cells that harbor ISAV in infected fish. The first in vivo fish experiments on ISAV were able to transmit the disease to naive fish using either tissue homogenates or blood collected from Atlantic salmon during a natural outbreak of ISA (Thorud \& Djuvik 1988, Christie et al. 1993). Using similar experiments, Dannevig et al. (1994) transmitted the virus to naive fish and caused disease with both the white blood cells and red blood cells from the head kidney of ISAV experimentally infected fish, indicating that the virus is present in all the different blood cells. Since then, the development of anemia in ISA has been taken to imply that erythrocytes are among the target cells for ISAV infection (Cipriano \& Miller 2003). Moreover, ISAV has been shown to agglutinate red blood cells of different fish species in vitro (Falk et al. 1997, Sommer \& Mennen 1997) suggesting that the virus might attach and/or replicate in erythrocytes in vivo. However, by using electron microscopy, virus replication could only be demonstrated in endothelial cells and leucocytes of infected fish (Hovland et al. 1994).

Infectious salmon anemia virus isolates vary in their pathogenicity, with the most virulent strains causing the highest mortalities in Atlantic salmon (>95\% mortality), and of the shortest duration (9 to $12 \mathrm{~d}$ ) (Kibenge et al. 2004). Isolate Norway 810/9/99 is highly pathogenic for Atlantic salmon, and at an inoculum dose of $10^{6} \mathrm{TCID}_{50}$ per fish, it causes mortality to begin at $10 \mathrm{~d}$ post-infection (dpi) which coin- 
cides with the peak viremia period (Moneke et al. 2005). Previous in situ hybridization (ISH) studies on ISAV-infected fish have not reported on viral mRNA in blood cells (Gregory 2002, Moneke et al. 2003) although we have occasionally observed ISH signals in some circulating blood cells suspected as erythrocytes and in some individual cells in the head kidney suspected to be hematopoietic cells (Moneke et al. 2004). It was therefore decided to use ISH to more specifically identify the circulating blood cell(s) carrying virus during viremia.

\section{MATERIALS AND METHODS}

Cells and viruses. The ISAV isolate Norway 810/9/99 used for this study was propagated and titrated in the TO cell line as described previously (Kibenge et al. 2001).

Riboprobe preparation. Preparation of the ISAV riboprobe was carried out as previously described (Moneke et al. 2003). Briefly, total RNA extracted from ISAV-infected cell culture lysate with Trizol Reagent (Invitrogen Life Technologies) was used in reverse transcription-polymerase chain reaction (RT-PCR) to obtain ISAV cDNA. The PCR primers consisted of ISAV RNA segment 7 (Ritchie et al. 2002, GenBank Acc. No. AF328627) forward primer 5'-ATG TCT GGA TTT AAC CTC GAG G-3' (nucleotides 133-154) and segment 7 reverse primer $5^{\prime}$-CAT AAC AAG TTT TCA ACC AAT C-3' (nucleotides 902-923) that yield a product $792 \mathrm{bp}$ long. One-step RT-PCR was carried out as previously described (Kibenge et al. 2000), using Titan-one tube RT-PCR kit (Roche Molecular Biochemicals). The RT-PCR product was first cloned in the $\mathrm{pCR}^{\circledR} \mathrm{II}-\mathrm{TOPO}{ }^{\circledR}$ Vector (Invitrogen Life Technologies) following the manufacturer's protocol. The insert DNA was then subcloned into pGEM-3Z vector (Promega) using the Rapid DNA Ligation Kit (Roche Molecular Biochemicals). The orientation of the DNA insert in the plasmid was determined by restriction enzyme analysis in order to allow generation off the T7 promoter, an antisense riboprobe of approximately 405 bases long. Thus the plasmid DNA was digested with $X b a$ I prior to use. The in vitro transcription reaction was carried out in presence of digoxigenin-11-deoxyuridine triphosphate (Digoxigenin-11-UTP, Roche Molecular Biochemicals) using a Riboprobe Combination SystemSP6/T7 kit (Promega) following the manufacturer's protocol. The digoxigenin-labeled RNA transcripts were purified by ethanol precipitation in high salt and were stored at $-80^{\circ} \mathrm{C}$ until used. The integrity, polarity, specificity and sensitivity of the riboprobe were checked by Northern blot hybridization as previously described (Moneke et al. 2003).
Fish experiment. A total of 23 Atlantic salmon certified as specific pathogen-free was obtained from the Atlantic Sea Smolts, Souris, Prince Edwards Island, Canada. The mean weight and length of fish at the start of experiment was approximately 15 to $20 \mathrm{~g}$ and $10 \mathrm{~cm}$, respectively. From the population, 3 fish were screened for ISAV by virus isolation attempts on the TO cell line and by RT-PCR to establish the ISAVnegative status of the stock before virus challenge. The fish were maintained in the Aquatic Animal Facility of the Atlantic Veterinary College in $1 \mathrm{~m}$ diameter fibreglass-reinforced plastic tanks using a fresh water flowthrough system at a temperature of approximately $11^{\circ} \mathrm{C}$. The fish were acclimatized for $2 \mathrm{wk}$ before use. The experimental procedures were performed in accordance with the guidelines of the Canadian Council of Animal Care (Olfert et al. 1993). A total of 17 fish was removed from stock holding tanks and anesthetized by immersion in an aerated solution of tricaine methane sulphonate (TMS-222) (100 $\left.\mathrm{mg} \mathrm{l}^{-1}\right)$ and each fish was challenged by intraperitoneal injection of $0.2 \mathrm{ml}$ of ISAV isolate Norway 890/9/99 at a virus dose $10^{6} \mathrm{TCID}_{50}$ and returned to the challenge tank. The negative control comprised 6 uninfected fish, which were kept in the control tank. All fish were observed twice daily for mortalities. Blood samples were collected in heparinized syringes from 3 infected fish and pooled on $6,8,10$, and $12 \mathrm{dpi}$, and from 3 uninfected controls on 6 and $12 \mathrm{dpi}$, before sacrifice. Blood smears were made immediately on clean glass slides and allowed to dry before fixing in either $4 \%$ paraformaldehyde for $30 \mathrm{~min}$ or methanol for $1 \mathrm{~min}$. Half of a pooled blood sample was transferred into $1.5 \mathrm{ml}$ heparinized microfuge tubes and centrifuged at $9718 \times g$. The other half of the blood sample was kept at $4{ }^{\circ} \mathrm{C}$ to allow the red blood cells to sediment. The different fractions of the hematocrit (packed erythrocytes, buffy coat, and plasma) were carefully collected and used to make smears on clean glass slides. In some cases there was a mixture of 2 adjoining fractions in the sample used for smears. The slides were fixed in $4 \%$ paraformaldehyde for $30 \mathrm{~min}$ and stored at $-80^{\circ} \mathrm{C}$ until used for ISH. The slides fixed in methanol were stained with Giemsa stain in order to identify the blood cell types.

ISH on blood smears. ISH was performed on the blood smears using the ISAV RNA segment 7 riboprobe following the procedure used for fish tissues (Moneke et al. 2003). Briefly, the blood smears were rehydrated in decreasing concentrations of ethanol to a final wash in diethyl pyrocarbonate (DEPC)-treated. The cells were permeabilized and then hybridized with approximately $25 \mathrm{ng}$ of the riboprobe in hybridization buffer per slide. ISH signals were developed using the Dig-UTP-Detection kit (Roche Diagnos- 
tics); they were then observed using light microscopy and the images captured digitally were enhanced and analyzed using Adobe Photoshop as previously described (Moneke et al. 2003).

\section{RESULTS AND DISCUSSION}

ISAV isolate Norway 810/9/99 was used for this study because it is highly pathogenic for Atlantic salmon, which was necessary in order to generate a high viremia. The blood samples were collected every $2 \mathrm{~d}$ beginning at $6 \mathrm{dpi}$ in order to obtain blood cells with maximum amounts of virus. The typical cellular composition of the blood smear of Atlantic salmon at 8 dpi with ISAV is shown in Fig. 1a. ISH signals were not observed in any blood fraction of the sample collected at 6 dpi (Fig. 1b). ISH signals were observed in leucocytes in smears of the buffy coat fraction at 8 dpi (Fig. 1c), and also at 10 and 12 dpi. No ISH signals were observed either in the red blood cells or in the cell-free plasma of the respective fractions at any time during the ISAV infection studied. No ISH signals were observed in any of the blood cells from the control fish. Typical clinical and histopathological signs of ISA including pale gills, ascites, congestion of the gut, enlargement of liver and spleen, and petechial hemorrhages in visceral organs (Evensen et al. 1991) were observed in fish bled and sacrificed beginning at $8 \mathrm{dpi}$. However, no mortalities were observed among the ISAV-infected fish in this study, probably because the moribund fish were sampled out during the period of acute viremia, 8 to $12 \mathrm{dpi}$.

For a virus to produce systemic disease it must be transported from the site of entry into the host to the target tissues (Tyler \& Fields 1996). The blood stream and nerves are 2 major pathways for virus spread in the host. ISAV has been shown to be transmitted outside the host via blood from infected fish (Dannevig et al. 1994), and also to spread in the host via blood (Hovland et al. 1994) leading to systemic disease (Evensen et al. 1991). The initial inoculation of virus into the host might result in passive viremia as a result of direct spread of the viral inoculum or due to limited replication at the primary site (primary viremia), before spreading to the target organs where more sustained replication and higher viral titers lead to secondary viremia (Tyler \& Fields 1996). Milkasen et al. (2001) using RT-PCR to detect virus after cohabitant exposure of Atlantic salmon with ISAV, reported that viraemic spread occurred rapidly after infection, but could not distinguish between passive transport of virus and active replicating virus followed by a decrease in viral load. The present study has used a high virus dose given by intraperitoneal injection to identify the leuco-
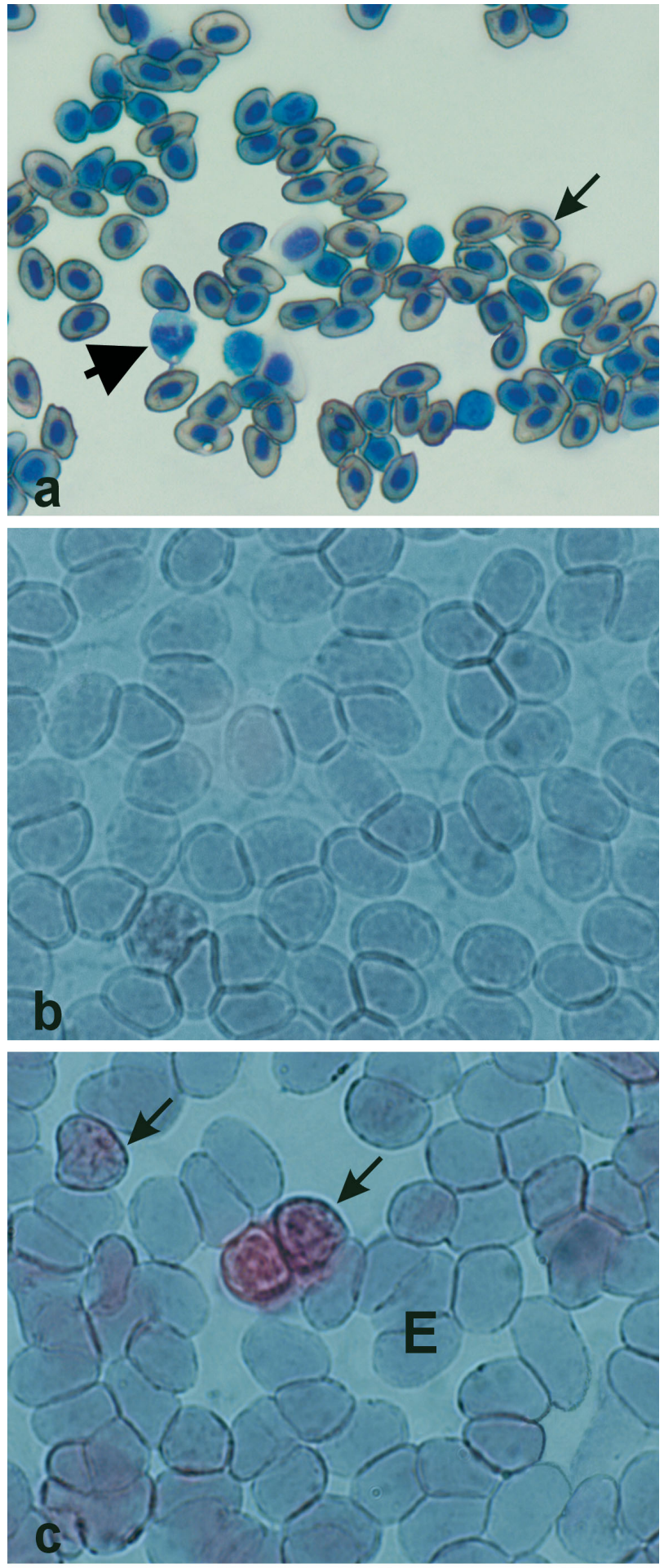

Fig. 1. Salmo salar. Blood of Atlantic salmon infected with ISAV isolate Norway 810/9/99. (a) Eight d post-infection (dpi); Giemsa stain, showing nucleated red blood cells (arrow) and leucocytes (large arrow). (b) Six dpi, no hybridization signal with ISAV segment 7 riboprobe was observed in any blood cells. (c) Eight dpi, presence of hybridization signals with ISAV segment 7 riboprobe in the leucocytes (arrow) and no signal in the surrounding erythrocytes (E) 
cytes as the blood cells that carry ISAV during viremia in experimentally infected fish. Since ISH procedure was used, only replicating virus was detected.

Viremia can be cell-associated as in neutrophilassociated influenza virus infection or cell-free as occurs in togavirus infections (Tyler \& Fields 1996). In this study, ISH signals were observed in the circulating leucocytes of ISAV-infected fish from 8 to $12 \mathrm{dpi}$, suggesting that the viremia in ISAV infection is, at least, cell-associated. The detection of ISH signals in leucocytes is consistent with other reports (Hovland et al. 1994, Koren \& Nylund 1997), which showed that ISAV replicates in these cells and that leucocytes are amongst the target cells for the virus. The absence of ISH signals in the leucocytes of blood samples collected at 6 dpi might be a result of low copy numbers of the viral mRNA present in the blood cells at that time, or due to increased clearance of infected leucocytes from the blood. The magnitude of viremia in a virus infection may vary as a result of dynamic interrelationships between the amount of virus entering the blood compartment and the efficiency with which it is removed (Tyler \& Fields 1996). The absence of ISH signals in the red blood cell fractions indicates that ISAV does not replicate in Atlantic salmon erythrocytes. However, we cannot rule out the possibility of an erythrocyte-associated viremia or even of a cell-free viremia in these fish, since the ISH technique used a negative-sense probe, and no effort was made to assay infectious virus or to assess the levels of viral genomic RNA by another method. Previous reports indicated that red blood cells harbor ISAV and transport it within infected fish (Dannevig et al. 1994). While the physical relationship between ISAV particles in blood and the circulating erythrocytes is not known, it is clear from our study that ISAV does not replicate in circulating red blood cells. This is consistent with data cited by Dannevig et al. (1993) which showed that in vitro inoculation of salmon erythrocytes or reticulocytes with infective ISA material did not result in ISAinfective cells as judged by transmission trials in fish.

In conclusion, this study demonstrates that viremia in ISAV infection is associated with virus replication in leucocytes, and that erythrocytes are not target cells for virus replication. Studies are in progress to establish the physical relationship (if any) between ISAV particles in blood and the circulating erythrocytes in ISAV-infected fish. Such studies may explain the erythrophagia frequently observed in sections of some organs of ISAV- infected fish such as the spleen.

Acknowledgments. This work was funded by the Natural Sciences and Engineering Research Council (NSERC) of Canada Strategic Grants and an NSERC Discovery Grant to F.S.B.K. and by AVC Departmental Laboratory supplies to B.O.I. The authors are grateful to Patricia McKenna and Greg Dobbin for technical assistance. We thank the animal welfare staff of Aquatic Animal facility of AVC, UPEI, for excellent care of the experimental fish.

\section{LITERATURE CITED}

Anonymous (2002) International committee on taxonomy of viruses, 00.046.0.05.001. Infectious Salmon Anaemia Virus (http://www.ncbi.nlm.nih.gov/ICTVdb/Ictv/index. $\mathrm{htm})$

Christie KE, Hjeltnes B, Winton JR (1993) Determination of buoyant density and sensitivity to chloroform and freon for the etiological agent of infectious salmon anaemia. Dis Aquat Org 15:225-228

Cipriano RC, Miller O Jr (2003) Infectious salmon anemia: The current state of our knowledge In: Miller O, Cipriano $\mathrm{RC}$ (eds) Tech coords. International response to infectious salmon anemia: prevention, control, and eradication: proceedings of a symposium, 3-4 September 2002, New Orleans, LA. Tech Bull 1902. Washington DC, U.S. Department of Agriculture, Animal and Plant Health Inspection Service, US Department of the Interior, US Geological Survey, US Department of Commerce, National Marine Fisheries Services, p 1-11

Dannevig BH, Falk K, Krogsrud J (1993) Leucocytes from Atlantic salmon, Salmo salar L., experimentally infected with infectious salmon anemia (ISA) exhibit an impaired response to mitogens. J Fish Dis 16:351-359

Dannevig BH, Falk K, Skjerve E (1994) Infectivity of internal organs and cells from Atlantic salmon (Salmo salar L.) experimentally infected with infectious salmon anemia. J Fish Dis 17:613-622

Evensen OKE, Thorud YA, Olsen (1991) A morphological study of the gross and light microscopic lesions of infectious anaemia in Atlantic salmon Salmo salar. Res Vet Sci 51:215-222

Falk K, Namork E, Rimstad E, Mjaaland S, Dannevig BH (1997) Characterization of infectious salmon anaemia virus, an orthomyxo-like virus isolated from Atlantic salmon Salmo salar L. J Virol 71:9016-9023

Gregory A (2002) Detection of infectious salmon anaemia virus (ISAV) by in situ hybridization. Dis Aquat Org 50:105-110

Hovland T, Nylund A, Watanabe K, Endresen C (1994) Observation of infectious salmon anemia virus in Atlantic salmon, Salmo salar L. J Fish Dis 17:291-296

Kibenge FSB, Lyaku JR, Rainnie D, Hammell K (2000) Growth of infectious salmon anaemia virus in CHSE-214 cells and evidence for phenotypic differences between virus strains. J Gen Virol 81:143-150

Kibenge FSB, Garate ON, Johnson G, Arriagada R, Kibenge MJT, Wadowska D (2001) Isolation and identification of infectious salmon anaemia virus (ISAV) from Coho salmon in Chile. Dis Aquat Org 45:9-18

Kibenge FSB, Munir K, Kibenge MJT, Joseph T, Moneke E (2004) Infectious salmon anemia virus: the causative agent, pathogenesis and immunity. Anim Health Res Rev 5:65-78

Koren CWR, Nylund A (1997) Morphology and morphogenesis of infectious salmon anaemia virus replicating in the endothelium of Atlantic salmon Salmo salar. Dis Aquat Org 29:99-109

Mikalsen AB, Teig A, Hellman A, Mjaaland S, Rimstad E (2001) Detection of infectious salmon anemia (ISAV) by RT-PCR after cohabitant exposure in Atlantic salmon Salmo salar. Dis Aquat Org 47:175-181

Moneke EE, Kibenge MJT, Groman D, Johnson GR, Ikede 
BO, Kibenge FSB (2003) Demonstration of infectious salmon anaemia virus (ISAV) RNA in fish cell cultures and in tissue sections of Atlantic salmon experimentally infected with ISAV. J Vet Diag Invest 15:407-417

Moneke EE, Groman DB, Wright GM, Stryhn H, Johnson GR, Ikede BO, Kibenge FSB (2005) Correlation of virus replication in tissues with histologic lesions in Atlantic salmon experimentally infected with infectious salmon anemia virus. Vet Pathol 42:338-349

Olfert ED, Cross BM, McWilliams A (1993) A guide to the care and use of experimental animals, 2nd edn. Bradda Printing Services, Ottawa

Ritchie RJ, Bardiot A, Melville K, Griffiths S, Cunningham

Editorial responsibility: Jo-Ann Leong,

Kaneohe, Hawaii, USA
CO, Snow M (2002) Identification and characterization of the genomic segment 7 of the infectious salmon anaemia virus genome. Virus Res 84:161-170

Sommer A, Mennen S (1997) Multiplication and haemadsorbing activity of infectious salmon anaemia virus in the established Atlantic salmon cell line. J Gen Virol 78: 1891-1895

Thorud K, Djupvik HO (1988) Infectious anaemia in Atlantic salmon Salmo salar L. Bull Eur Assoc Fish Pathol 8:109-111

Tyler KL, Fields BN (1996) Pathogenesis of viral infections. In: Fields BN, Knipe DM, Howley PM, Chanock RM, Melnick JL, Monath TP, Roizman B, Straus SE (eds) Virology, 3rd edn. Raven Press, New York, p 173-218

Submitted: May 6, 2004; Accepted: April 14, 2005

Proofs received from author(s): August 29, 2005 